\title{
Environmental factors affecting lactation curve parameters in the United Kingdom's commercial dairy herds
}

\author{
Factores ambientales que determinan los parámetros de la curva de lactación usando \\ un modelo biológico en rebaños lecheros comerciales en el Reino Unido \\ B Albarrán-Portillo ${ }^{a^{*}}$, GE Pollott ${ }^{\mathrm{b}}$ \\ ${ }^{a}$ Centro Universitario UAEM Temascaltepec, Universidad Autónoma del Estado de México, México.

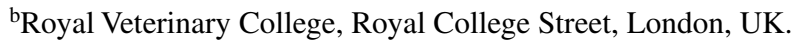

\begin{abstract}
RESUMEN
El objetivo del trabajo fue determinar los factores ambientales que determinan los parámetros de la curva de lactación utilizando un modelo biológico de ajuste de curva. El modelo propuesto ajusta dos curvas logísticas que simulan el incremento inicial en el número de células secretoras de leche en la lactación temprana, y la progresión de la apoptosis en la lactación tardía. Se analizaron lactaciones de 182.987 vacas Holstein-Friesian. Los factores vaca, rebaño y número de lactación explican el $74 \%$ de la suma total de cuadrados $(\mathrm{P}<0,001)$. La edad promedio a primer parto fue de 28 meses, teniendo un efecto significativo sobre la mayoría de los parámetros de la curva. Incrementos en la edad a primer de parto (20-40 meses) fueron asociados con incrementos lineales en los rendimientos totales de leche. Los parámetros tasa máxima de secreción y máximo de lactación estuvieron altamente correlacionados entre sí, indicando que son virtualmente los mismos. Adicionalmente, altos valores de estos dos parámetros indican altos rendimientos totales de leche. El día del máximo de lactación se correlacionó negativamente $(0,64)$ con persistencia de la lactación. Los factores vaca, rebaño número de lactación y edad a primer parto fueron los factores más determinantes sobre los parámetros de la curva de lactación de vacas de primera lactancia así como de lactaciones múltiples.
\end{abstract}

Key words: biological model, dairy cow, environmental factors, lactation curve.

Palabras clave: modelo biológico, vaca lechera, factores ambientales, curva de lactación.

\section{INTRODUCTION}

Several empirical models have been used to fit the lactation curve accounting for factors affecting milk yields (Masselin et al 1987). The incomplete gamma function proposed by Wood (1967), has been extensively used to fit lactation curves. This model accounts for the main parameters of the lactation curve such as: milk yield at the start of lactation, rate of increase to peak yield, and persistency of lactation. Most recently, other methods such as random regression models (Schaeffer and Dekkers 1994), and spline models (White et al 1999, Misztal 2006), have been used with good results. However, the parameters resulting from these models do not reflect the biological processes of lactation in its parameters (Pollott 2000).

Pollott (2000) developed a model which produces parameters with a biological explanation of lactation curve. This biological model accounts for mammary parenchyma cell proliferation, their differentiation into secretory cells and depletion of cell population due to programmed cell death (apoptosis) (figure 1). These processes have been

Accepted: 12.01.2011.

* Carretera Toluca-Tejupilco Km 67.5, Estado de México, C.P.51300; bapbap24@yahoo.com.mx reported extensively by Knight and Wilde (1987, 1993), Wilde and Knight $(1988,1989)$ and Wilde et al (1997).

Pollott's model produce three biological base parameters: Maximum secretion potential (MS), which is a function of the total number of parenchyma cells, and the maximum secretion rate $(\mathrm{kg} / \mathrm{cell}$ per day); the relative growth rate in cell numbers from parturition to peak yield; and the relative death rate in cell numbers from mid to the end of lactation. In this way the model provides parameters with a biological meaning, covering those parameters by Wood's model, complementing in this way, parameters that describe the shape of the lactation curve.

The biological model consists of seven parameters which under commercial milk records schemes (monthly records) it is not possible to use, since some lactations contain as few as 4 records, causing an over parameterization in case of use this model. That is why a reduced version of Pollott's model with two or three parameters have been developed, and were compare with some widely used models such as Wood, the model of Grossman and Koops (1988), and Morant and Gnanasakthy (1989), using dairy sheep and dairy cow lactations, with monthly records. In both cases, the results showed that the reduced version of the biological model with two and three parameters, produced residual mean squares that are smaller or similar when comapred to the other models (Pollott and Gootwine 2000). 


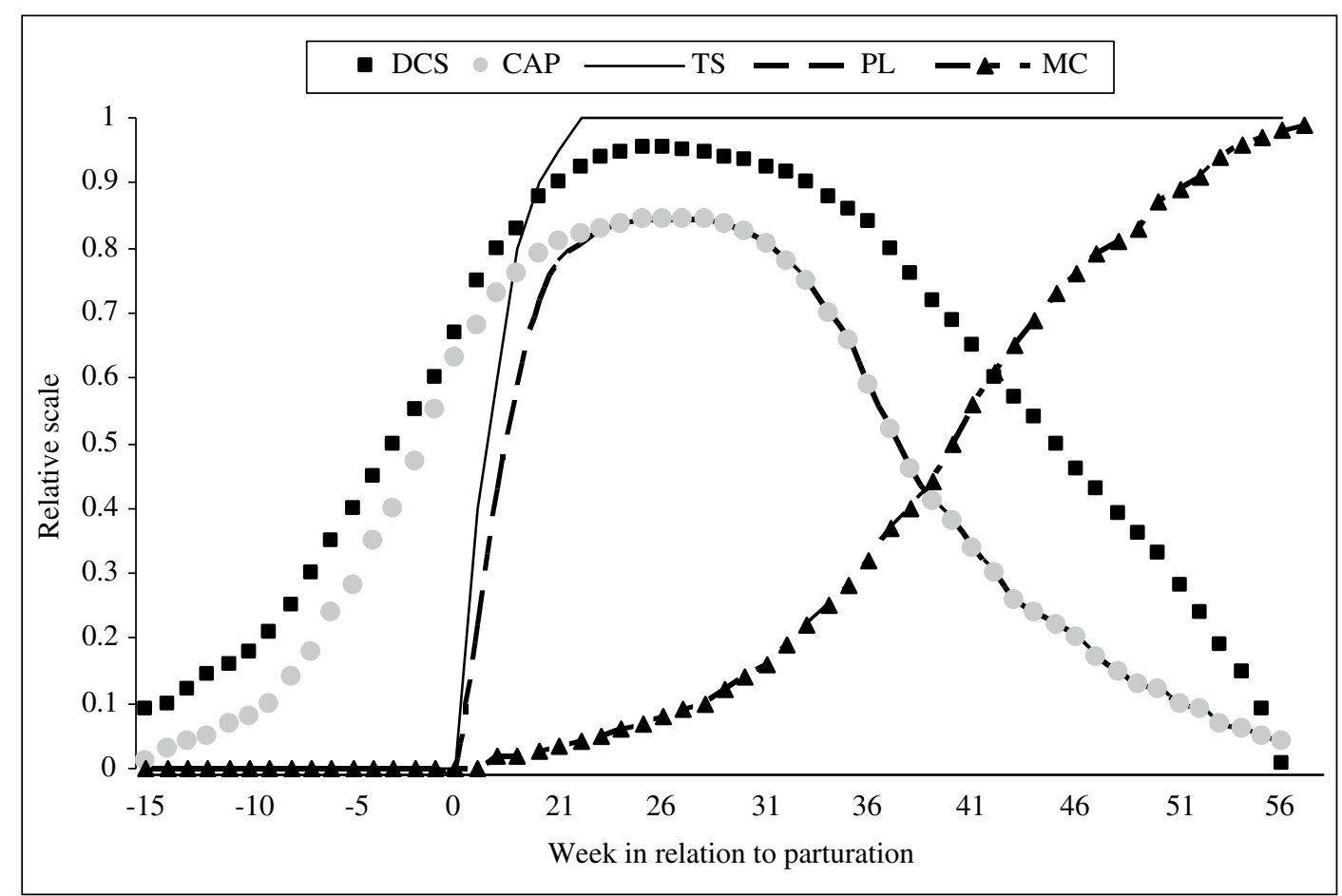

Figure 1. A schematic diagram of the lactation curve showing the essential features of the biological model. The number of differentiated parenchyma cells ( $\mathbf{\square})$ combines with the cell secretion rate (-) to give the maximum secretion potential of the mammary gland. The proportion of active cells dying due to apoptosis $(\mathbf{A})$ decreases the number of active cells in mid to late lactation. The number of active cells multiplied by the cell secretion rate gives the milk yield (-).

Diagrama esquemático de la curva de lactación que muestra las características esenciales del modelo biológico. Número de células diferenciadas del parénquima (ם), combinada con la tasa de secreción por célula (-), para dar el potencial máximo de secreción de la glándula mamaria. Proporción de muerte de células activas debido a apoptosis $(\boldsymbol{\Delta})$, disminución en el número de células activas de lactación media al final de la lactación. Rendimiento de leche producto del número de células activas y de la tasa de secreción (—).

Albarrán-Portillo and Pollott (2008) used the biological two-parameter model, using commercial monthly records with as little as 4 test-day records, in order to estimate the genetic factors affecting lactation curve parameters from commercial dairy herds, proving the genetic relationship among output parameters from the biological model. They concluded that biological parameter maximum secretion potential (MS), and proportional reduction in cell numbers (DR), did not show a high genetic correlation among them, making them subjected to selection. The parameter MS, and its genetic correlated parameters like peak yield, implies higher milk yields, where as lower values of DR, implies more persistent lactations, that results in higher total milk yields.

Milk production, apart from the genetic merit of the cow, is affected by several environmental factors that must be considered in order to estimate accurately total milk yields. Such factors are herd, year and season of calving, lactation number, and age at first calving among some others (Lee et al 1995, Brotherstone et al 2004).

The aim of this research was to use a two-parameter biological model to fit lactation curves of dairy cows from commercial herds, with the purpose of determining the environmental factors affecting lactation curve parameters.

\section{MATERIAL AND METHODS}

DATA

The data used in this research came from a large database provided by National Milk Records Ltd. (Chippenham, UK), from commercial dairy herds in the United Kingdom. Lactations were composed by monthly records, and to be used in this analysis they were edited as follows: lactations with first test day recorded after d 80 of lactation were deleted, as were lactations with $<4$ test-day records (TD). Cows younger or older than 20 months of age at first calving were deleted. Lactations were grouped according to lactation number; eight groups were formed. Lactation group number eight was composed by lactations $\geq 8$.

The final database included 392,954 lactations from 182,987 cows from 431 dairy herds that remain in the database. Number of test-day records per lactation ranged from 4 to 15 , with an average of 10 TD per lactation. 
MODEL

Lactations curves were fitted using the 2-parameter multiplicative model (Model 1). This model is an alternative to the original 7-parameters multiplicative model (Pollott 2000), and was used for the first time by Pollott and Gootwine (2000), who would have had the difficulty of fitting a model with 7 parameters to farm recorded monthly test-day records.

The 2-parameter model was:

$M_{t}=\frac{\left.\left(M S /\left\{1+z e^{[-0.1(t-150)}\right]\right\}\right)}{S_{a} x N D P C} \frac{\left\{2-e^{[D R(t-150)]}\right\}}{P R}$

where $\mathrm{M}_{t}=$ Milk yield on $t$ day of lactation; MS = the maximum secretion potential of lactation; $z=[(1-0.9999999) / 0.9999999] ;$ and DR $=$ the relative decline in cell numbers as lactation progresses (Pollott and Gootwine 2000, Pollott and Gootwine 2001). Basically, the model comprised 2 logistic curves (figure 1). The first curve accounted for the increase in cell numbers during early lactation as a function of time. Specifically, the first part of the equation estimated MS as the maximum secretion rate of milk as the product of the average secretion rate per cell (Sa), and the number of differentiated parenchyma cells (NDPC). The second logistic curve determined the down slope of the lactation (after peak yield) due to the relative death rate of cells as a function of time, the proportional reduction in cell numbers (PR) as lactation progresses (Pollott 2000).

\section{CURVE FITTING}

Curves were fitted to each of the 392,954 lactations using the 2-parameter biological model with an iterative nonlinear curve fitting procedure (NLIN) in SAS (SAS Institute 1999). The iterative process was initiated using preliminary estimates of the parameters [e.g., $\mathrm{MS}=0.1$ to 85 (bounds $0 \mathrm{MS}<85$ ) and DR $=0.000001$ to 0.1 (bounds $-1<\mathrm{DR}<1)]$. The best fit of the model with respect to a particular lactation was obtained when the differences between the residual sums of squares in successive iterations was $<10^{-6}$ (Albarran-Portillo and Pollott 2008).

\section{CURVE PARAMETERS}

The outcome parameters from the model MS and DR, were complemented with calculated values of the lactation curve such as growing midpoint from the start of lactation to peak yield (GM), peak yield (PY), day of peak (DP), persistency (PS) which was estimated at the midpoint between peak yield and the end of lactation, observed total milk yield (TMY) and calculated total milk yield (CTMY)
(Pollott 2000). Total milk yield was the lactation milk yield calculated from the original test-day records using the test-interval method of Sargent et al (1968).

\section{STATISTICAL ANALYSIS OF LACTATION PARAMETERS}

Lactations were analysed using Model 2 in order to determinate the environmental factors that affect lactation curve traits. The model was fitted to the 8 lactation parameters shown in table 1, using GLM procedure (SAS 1989).

$M_{t}=\frac{\left(M S /\left\{1+z e^{[-0.1(t-150)]}\right\}\right)\left\{2-e^{[D R(t-150)]}\right\}}{S_{a} x N D P C} \frac{\{R}{P R}$

where $\mu=$ overall least square mean, $\mathrm{C}_{i}=\operatorname{Cow}(i=1$ to 182,987) $\mathrm{H}_{j}=$ herd $j(j=1$ to 431$)$, and $\mathrm{YR}_{k}=$ calving year $k$ ( $k=1994$ to 2003), and $\mathrm{S}_{l}=$ season of calving ( $l=$ spring to winter), and $\mathrm{LNO}_{m}=$ lactation number $m(m=1$ to $\geq 8)$, and $e_{i j k l}$ represents the random error term. Due to the large number of levels of factor cow, it was absorbed from the analysis using the Absorb statement in GLM procedure, in order to reduce time and computing memory resources, since there are no interactions between cow and the main factors (SAS 1989). Least square means were computed for each of the factors in the model, except for the factor absorbed.

The ANOVA analysis results used Type III sums of squares, and least square means were computed for each of the factors in the model.

\section{AGE AT FIRST CALVING}

In order to determine the effect of age at first calving (AFC) on milk production first, second and third lactations were selected from the main data set to be analyzed. The characteristics of each lactation were: record of date of birth and date of calving, cows younger than 20 months and older than 40 months at first calving were excluded from the analysis. Model 2 was fitted to first, second and third lactation records $(119,580,74,986$ and 18,498 lactations, respectively). Afterward, lactation number (LNO), was omitted from the model and instead AFC and $\mathrm{AFC}^{2}$ were included as covariates. The reason to include $\mathrm{AFC}^{2}$ in the analysis was due to the fact that AFC has a curvilinear effect on lactation traits (Pollott 2004).

\section{CORRELATION ANALYSIS}

Correlation analyses were carried out between the eight lactation curve parameters, fitting Model 2 to all traits using the MANOVA option in GLM procedure in SAS (1989). 


\section{RESULTS}

The average values of the traits (table 1 ) were as follow: MS was $36.0(\mathrm{~kg} / \mathrm{d})$, peak yield (PY) was $33.5(\mathrm{~kg} / \mathrm{d})$, growing midpoint from the start of lactation to PY (GM) $201 \mathrm{~g} / \mathrm{d}$, reaching peak yield at day 34 of lactation.

The relative death rate in cell numbers (DR) was 0.0014, and persistency (PS) (decreasing midpoint between PY and the end of lactation) was $76.3(\mathrm{~g} / \mathrm{d})$. Total milk yield (TMY) was 7,844 kg; while calculated total milk yield (CTMY) was $8,153 \mathrm{~kg}$.

\section{CORRELATIONS}

Phenotypic correlations among traits are shown in table 2 . All correlations were highly significant $(\mathrm{P}<0.001)$, even though some of the correlations were rather small. Parameters from the increasing phase of lactation such as MS, GM, PY, were well correlated amongst themselves $(>0.60)$. High estimates of MS and PY resulted in high total milk yield as indicated by the high correlations of these two traits with TMY and CTMY.

Growing midpoint from the start of lactation to PY (GM) was fairly well correlated with DR, DM, TMY, and CTMY. The high correlation of GM with PY implied that the increased of GM affected positively PY; while the high negative correlation of GM with DP implied an early day of peak.

The early day of peak had an unfavorable effect over persistency of lactation given by the high correlation between DP and PS (0.64).

Table 1. Means, standard deviations and factor cow, herd $(\mathrm{H})$, year $(\mathrm{Y})$, season (SE) of calving, and lactation number (LNO) affecting lactation curve parameters.

Promedio, desviaciones estándares y la influencia de los factores vaca, hato, año, época de parto y número de lactación, sobre los parámetros de la curva.

\begin{tabular}{|c|c|c|c|c|c|c|c|c|}
\hline & Mean & SD & $\mathrm{R}^{2}$ & Cow & $\mathrm{H}$ & $\mathrm{Y}$ & SE & LNO \\
\hline Maximum secretion potential (MS) (k/d) & 36.0 & 5.76 & 0.83 & $* * *$ & $* * *$ & $* * *$ & $* * *$ & $* * *$ \\
\hline $\begin{array}{l}\text { Growing midpoint from the start of lactation to peak } \\
\text { yield }(\mathrm{GM})(\mathrm{g} / \mathrm{d})\end{array}$ & 201 & 58.31 & 0.85 & $* * *$ & $* * *$ & $* * *$ & $* * *$ & $* * *$ \\
\hline Peak yield (PY) (k/d) & 34.0 & 5.44 & 0.84 & $* * *$ & $* * *$ & $* * *$ & $* * *$ & $* * *$ \\
\hline Day of peak (DP) (d) & 34 & 7.17 & 0.74 & $* * *$ & $* * *$ & $* * *$ & $* * *$ & $* * *$ \\
\hline Relative decline in cell numbers (DR) & 0.0014 & 0.0004 & 0.75 & $* * *$ & $* * *$ & $* * *$ & $* * *$ & $* * *$ \\
\hline Persistency (PS) (g/d) & 76.0 & 41.65 & 0.88 & $* * *$ & $* * *$ & $* * *$ & $* * *$ & $* * *$ \\
\hline Total milk yield (TMY) (kg) & 7.844 & 1937.21 & 0.83 & $* * *$ & $* * *$ & $* * *$ & $* * *$ & $* * *$ \\
\hline Calculated total milk yield (CTMY) (kg) & 8.153 & 1949.24 & 0.79 & $* * *$ & $* * *$ & $* * *$ & $* * *$ & $* * *$ \\
\hline
\end{tabular}

**** $\mathrm{P}(<0.001)$.

Table 2. Phenotypic correlation coefficients between curve parameters (standard errors shown below in parenthesis). Coeficientes de correlación fenotípicos entre los parámetros de la curva (errores estándares mostrados debajo del paréntesis).

\begin{tabular}{|c|c|c|c|c|c|c|c|}
\hline & GM & PY & DP & DR & PS & TMY & CTMY \\
\hline Maximum secretion potential (MS) $(\mathrm{kg} / \mathrm{d})$ & $\begin{array}{c}0.62 \\
(0.001)\end{array}$ & $\begin{array}{c}0.99 \\
(0.001)\end{array}$ & $\begin{array}{c}0.03 \\
(0.004)\end{array}$ & $\begin{array}{c}0.12 \\
(0.004)\end{array}$ & $\begin{array}{c}0.29 \\
(0.002)\end{array}$ & $\begin{array}{l}0.86 \\
(0.001)\end{array}$ & $\begin{array}{l}0.76 \\
(0.001)\end{array}$ \\
\hline $\begin{array}{l}\text { Growing midpoint from the start of lactation to } \\
\text { peak yield }(\mathrm{GM})(\mathrm{g} / \mathrm{d})\end{array}$ & & $\begin{array}{c}0.60 \\
(0.002)\end{array}$ & $\begin{array}{c}0.62 \\
(0.002)\end{array}$ & $\begin{array}{c}0.38 \\
(0.001)\end{array}$ & $\begin{array}{l}-0.31 \\
(0.002)\end{array}$ & $\begin{array}{l}0.40 \\
(0.001)\end{array}$ & $\begin{array}{l}0.31 \\
(0.003)\end{array}$ \\
\hline Peak yield (PY) (kg/d) & & & $\begin{array}{l}0.04 \\
(0.075)\end{array}$ & $\begin{array}{c}0.06 \\
(0.004)\end{array}$ & $\begin{array}{c}0.27 \\
(0.003)\end{array}$ & $\begin{array}{l}0.89 \\
(0.001)\end{array}$ & $\begin{array}{l}0.78 \\
(0.001)\end{array}$ \\
\hline Day of peak (DP) (d) & & & & $\begin{array}{l}-0.12 \\
(0.003)\end{array}$ & $\begin{array}{c}0.64 \\
(0.004)\end{array}$ & $\begin{array}{c}0.07 \\
(0.004)\end{array}$ & $\begin{array}{c}0.08 \\
(0.004)\end{array}$ \\
\hline Relative decline in cell numbers (DR) & & & & & $\begin{array}{c}0.39 \\
(0.004)\end{array}$ & $\begin{array}{l}-0.31 \\
(0.004)\end{array}$ & $\begin{array}{l}-0.39 \\
(0.004)\end{array}$ \\
\hline Persistency (PS) (g/d) & & & & & & $\begin{array}{c}0.09 \\
(0.004)\end{array}$ & $\begin{array}{c}0.04 \\
(0.004)\end{array}$ \\
\hline Total milk yield $(\mathrm{TMY})(\mathrm{kg})$ & & & & & & & $\begin{array}{l}0.90 \\
(0.001)\end{array}$ \\
\hline
\end{tabular}

$* * * \mathrm{P}<0.001$ indicates significantly different from 0 . 
Decreasing rate in cell numbers was modestly correlated with PS (0.39), and negatively correlated with TMY and CTMY $(-0.31,-0.39$, respectively).

Observed total milk yields (TMY) and CTMY were highly correlated (0.90). These two parameters were highly correlated with MS and PY $(>0.60)$; moderately correlated with GM. They were low correlated with DP and with PS. Uncorrelated or low correlated traits like PS with TMY are desirable, due to the fact that for example increments of TMY will not affect DM or its effects will be low. The negative correlation of TMY $(-0.31)$ and CTMY $(-0.39)$ with DR are desirable due to increments of total milk yields had a positive impact on DR.

\section{ENVIRONMENTAL FACTORS AFFECTING TRAITS}

Table 1 shows the results of the analysis of variance of the parameters. All factors in the model were highly significant $(\mathrm{P}<0.001)$ to the curve parameters. The determination coefficient $\left(\mathrm{R}^{2}\right)$ ranged from 0.74 to 0.88 for DP and PS respectively. Thus, the model accounted for a large proportion of the variance of curve parameters.

As expected, the most important factors were cow, herd and lactation number which accounted for $0.39,0.25$ and 0.10 of the total sum of squares (TSS) respectively; whereas year and season of calving accounted for less than 0.02 of the TSS of curve parameters.

Calving year. Table 3 shows the least squares means of the lactation curve parameters according to calving year. As a general trend, initial values for MS, GM, PY, DP, PS, TMY and CTMY increased over the years analyzed. Values for DR and PS increased over the years implicating less persistency of lactation as milk yields increased.

Calving season. Table 4 shows the results of the analysis of the effects of calving season on curve parameters. Spring and winter were the seasons where MS, GM PY and CTMY, recorded the highest yields, compared to summer and autumn. Total milk yield reached the highest level in winter followed by autumn, rather than winter, as in CTMY and the rest of the parameters mentioned above.

Lactations starting in summer and autumn were more persistent than lactations starting in winter or spring. Decreasing rate in cell numbers (DR) had significantly lower values in autumn and winter rather than in spring and summer.

Lactation number. Lactation number had a significant effect over curve parameters. Table 5 shows the average values of curve parameters according to lactation number. As expected, first lactation had the lowest values of MS, GM, PY, DR, PS, TMY and CTMY, compared with the

Table 3. Least squares means of parameters by year of calving.

Promedio de cuadrados mínimos para los parámetros de la curva por año de parto.

\begin{tabular}{ccccccccccc}
\hline \multirow{2}{*}{ Year } & $\mathrm{n}=$ & $\mathrm{MS}$ & $\mathrm{GM}$ & $\mathrm{PY}$ & $\mathrm{DP}$ & $\mathrm{DR}$ & $\mathrm{PS}$ & \multicolumn{2}{c}{ TMY } & CTMY \\
\cline { 2 - 10 } & & $\mathrm{kg}$ & $\mathrm{g} / \mathrm{kg}$ & $\mathrm{kg}$ & $\mathrm{d}$ & & $\mathrm{g} / \mathrm{d}$ & $\mathrm{kg}$ & $\mathrm{kg}$ \\
\hline 1994 & 246 & 32 & 203 & 30 & 32 & 0.0016 & 77 & 6.619 & 6.770 \\
1995 & 1.165 & 33 & 203 & 30 & 32 & 0.0016 & 81 & 6.644 & 6.646 \\
1996 & 3.715 & 34 & 206 & 31 & 33 & 0.0016 & 82 & 6.889 & 6.931 \\
1997 & 11.373 & 35 & 213 & 32 & 33 & 0.0016 & 86 & 7.071 & 7.261 \\
1998 & 28.065 & 35 & 215 & 33 & 33 & 0.0016 & 87 & 6.997 & 7.102 \\
1999 & 44.712 & 36 & 222 & 34 & 33 & 0.0017 & 91 & 7.194 & 7.296 \\
2000 & 60.452 & 36 & 216 & 34 & 34 & 0.0016 & 87 & 7.507 & 7.686 \\
2001 & 79.802 & 38 & 223 & 35 & 34 & 0.0015 & 88 & 7.936 & 8.206 \\
2002 & 94.028 & 38 & 223 & 36 & 34 & 0.0015 & 87 & 8.166 & 8.536 \\
2003 & 68.999 & 39 & 224 & 36 & 34 & 0.0015 & 86 & 8.224 & 8.499 \\
\hline
\end{tabular}

MS = Maximum secretion potential; GM = Growing midpoint from the start of lactation to peak yield; PY = Peak yield; DP = Day of peak; DR = relative decline in cell numbers; PS = persistency; TMY = Total milk yield; CTMY = Calculated total milk yield

Table 4. Least squares means effect of calving season on lactation curve parameters.

Promedio de cuadrados mínimos del efecto de la época de año sobre los parámetros de la curva.

\begin{tabular}{|c|c|c|c|c|c|c|c|c|c|}
\hline \multirow{2}{*}{ Season } & \multirow[b]{2}{*}{$\mathrm{n}=$} & MS & GM & PY & DP & DR & PS & TMY & CTMY \\
\hline & & $\mathrm{kg}$ & $\mathrm{g} / \mathrm{d}$ & $\mathrm{kg}$ & $d$ & & $\mathrm{~g} / \mathrm{d}$ & $\mathrm{kg}$ & $\mathrm{kg}$ \\
\hline Spring & 78.272 & $36^{\mathrm{a}}$ & $229^{a}$ & $33.9^{\mathrm{a}}$ & $32.5^{\mathrm{a}}$ & $0.00169^{a}$ & $92^{\mathrm{a}}$ & $7.018^{\mathrm{a}}$ & $7.194^{\mathrm{a}}$ \\
\hline Summer & 74.456 & $35^{\mathrm{b}}$ & $217^{\mathrm{b}}$ & $32.6^{\mathrm{b}}$ & $32.6^{\mathrm{a}}$ & $0.00164^{\mathrm{b}}$ & $86^{\mathrm{b}}$ & $6.850^{\mathrm{b}}$ & $7.044^{\mathrm{b}}$ \\
\hline Autumn & 132.428 & $35^{\mathrm{c}}$ & $202^{c}$ & $32.3^{c}$ & $33.6^{\mathrm{b}}$ & $0.00152^{\mathrm{c}}$ & $83^{c}$ & $7.075^{\mathrm{c}}$ & $7.085^{\mathrm{c}}$ \\
\hline Winter & 107.802 & $36^{\mathrm{a}}$ & $220^{d}$ & $34.1^{\mathrm{a}}$ & $33.1^{\mathrm{c}}$ & $0.00158^{\mathrm{d}}$ & $88^{\mathrm{d}}$ & $7.305^{\mathrm{d}}$ & $7.400^{\mathrm{d}}$ \\
\hline
\end{tabular}


Table 5. Effect of lactation number over lactation curve parameters.

Efecto del número de lactación sobre los parámetros de la curva.

\begin{tabular}{|c|c|c|c|c|c|c|c|c|}
\hline LNO & 1 & 2 & 3 & 4 & 5 & 6 & 7 & 8 \\
\hline $\mathrm{n}=$ & 125,468 & 100,408 & 71,187 & 46,404 & 27,306 & 13,642 & 5,499 & 3,044 \\
\hline $\mathrm{MS}(\mathrm{kg} / \mathrm{d})$ & $27.8^{\mathrm{a}}$ & $35.2^{b}$ & $37.8^{c}$ & $38.4^{\mathrm{d}}$ & $38.0^{\mathrm{c}}$ & $37.1^{\mathrm{e}}$ & $35.9^{f}$ & $33.7^{\mathrm{g}}$ \\
\hline $\mathrm{GM}(\mathrm{g} / \mathrm{d})$ & $145^{\mathrm{a}}$ & $208^{b}$ & $230^{c}$ & $236^{\mathrm{d}}$ & $237^{d}$ & $233^{\mathrm{cd}}$ & $228^{c}$ & $219^{\mathrm{e}}$ \\
\hline PY (kg) & $26.5^{\mathrm{a}}$ & $33.0^{\mathrm{b}}$ & $35.4^{\mathrm{c}}$ & $35.9^{d}$ & $35.5^{\mathrm{c}}$ & $34.6^{\mathrm{e}}$ & $33.4^{\mathrm{b}}$ & $31.4^{\mathrm{f}}$ \\
\hline $\mathrm{DP}(\mathrm{d})$ & $33.7^{\mathrm{a}}$ & $33.0^{\mathrm{b}}$ & $33.2^{\mathrm{c}}$ & $33.3^{\mathrm{c}}$ & $33.1^{\mathrm{bc}}$ & $32.8^{\mathrm{bc}}$ & $32.6^{\mathrm{bcd}}$ & $31.9^{d}$ \\
\hline DR & 0.0012 & $0.0015^{\mathrm{b}}$ & $0.0016^{\mathrm{c}}$ & $0.0017^{\mathrm{d}}$ & $0.0017^{\mathrm{e}}$ & $0.0017^{\mathrm{e}}$ & $0.0018^{\mathrm{f}}$ & $0.0018^{\mathrm{f}}$ \\
\hline PS (g/d) & $49.9^{\mathrm{a}}$ & $80.7^{b}$ & $92.1^{\mathrm{c}}$ & $95.9^{\mathrm{de}}$ & $97.4^{\mathrm{de}}$ & $96.5^{\text {de }}$ & $95.5^{\mathrm{cde}}$ & $89.8^{c}$ \\
\hline TMY (kg) & $6,369^{a}$ & $7,341^{\mathrm{b}}$ & $7,650^{\mathrm{c}}$ & $7,628^{c}$ & $7,426^{\mathrm{d}}$ & $7,132^{\mathrm{e}}$ & $6,756^{\mathrm{f}}$ & $6,192^{\mathrm{g}}$ \\
\hline CTMY (kg) & $6,659^{\mathrm{a}}$ & $7,550^{\mathrm{b}}$ & $7,822^{\mathrm{c}}$ & $7,763^{\mathrm{c}}$ & $7,521^{\mathrm{b}}$ & $7,195^{\mathrm{d}}$ & $6,779^{a}$ & $6,157^{\mathrm{e}}$ \\
\hline
\end{tabular}

LNO = Lactation number; Superscript if different statistically significant $\mathrm{P}<0.05$.

rest of the lactations. Low values of DM in first lactations implicated better persistency than the rest of the lactations.

As lactation number increased levels of MS, GM, PY, TMY and CTMY increased, up to around lactation number 3 and 4, from where yields started to decline.

Effect of age at first calving. Table 6 shows means and standard deviation of the curve parameters, as well as the results of ANOVA analysis of age at first calving (AFC) and $\mathrm{AFC}^{2}$ for first and second lactations.

Figure 2 shows the effects of AFC (in months) over CTMY for first and second lactations. For every month of increase in age at first calving, CTMY and TMY increased by 36.3 and $28.0 \mathrm{~kg}$ of milk, respectively.

In respect of TMY and CTMY in second lactation, there were on average monthly increments of 10.5 and $7.2 \mathrm{~kg}$ of milk, respectively between 20 and 29 months of AFC (not significant $\mathrm{P}>0.05$ ). While for heifers calving for the first time at an age older than $29 \mathrm{mo}$; on average
TMY and CTMY decreased 11.8 and $8.8 \mathrm{~kg}$ per mo, as AFC increased.

Hence, the increment of age at first calving from 20 to $40 \mathrm{mo}$, was associated with linear increments in TMY and CTMY in first lactations. While for second lactations, there was a significant effect on TMY and CTMY due to age at first calving.

\section{EFFECT OF YEAR OF CALVING IN FIRST LACTATION}

First lactation curve parameters analyzed by year of calving showed a very similar trend to parameters showed in table 3, where all lactations were analyzed together, but to a lower extent. The whole parameters showed an increase along with the year of calving.

The annual average increment in TMY and CTMY for first calving cows was 120 and $121 \mathrm{~kg}$, respectively. However, from year 1998 to 2003 the average increment in TMY and, CTMY were higher than before year 1998.

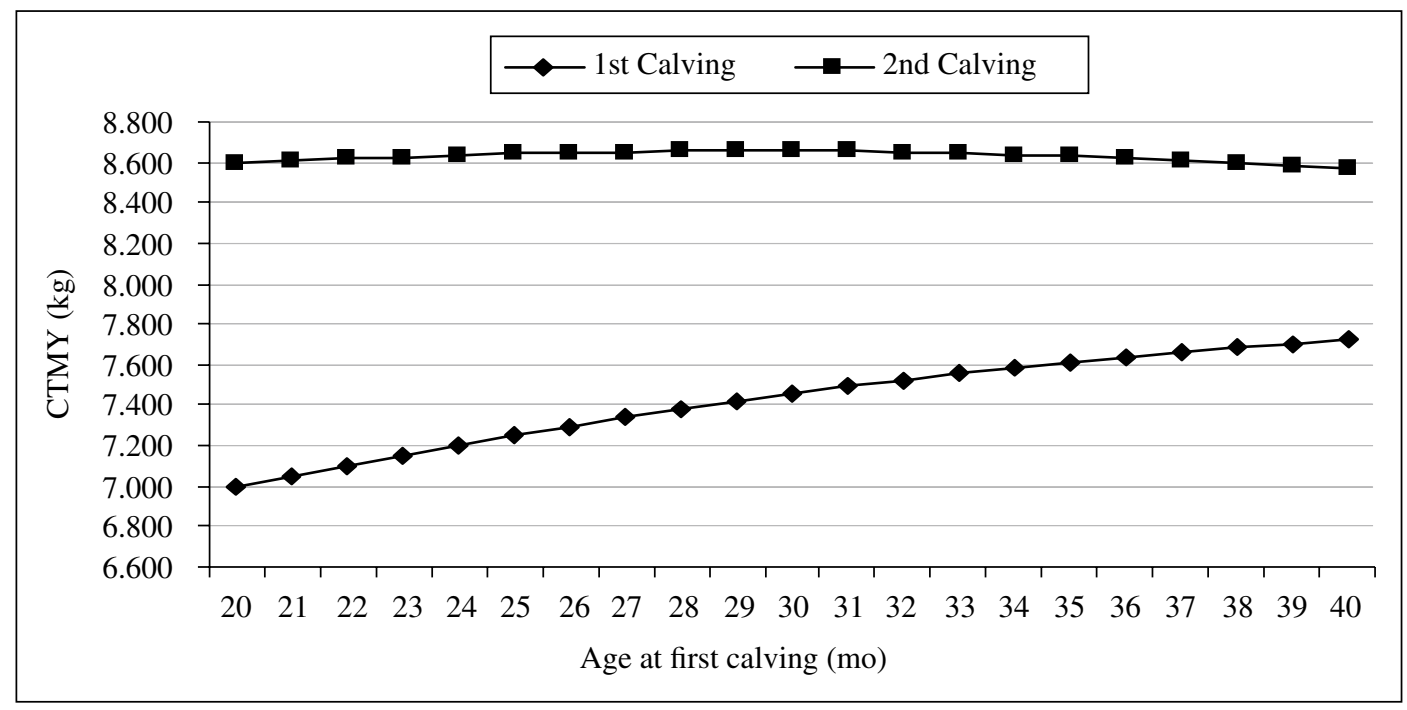

Figure 2. Effect of age at first calving in calculated total milk yield (CTMY) in first and second lactation. Efecto de la edad a primer parto sobre la producción total de leche calculada (CTMY), en la primera y segunda lactación. 
Table 6. ANOVA analysis for age at first calving on first lactation curve traits.

Análisis de varianza del efecto de la edad a primer parto sobre los parámetros de la curva.

\begin{tabular}{|c|c|c|c|c|c|c|c|c|}
\hline & \multicolumn{4}{|c|}{ First Lactation $\mp$} & \multicolumn{4}{|c|}{ Second lactation $\mathrm{z}$} \\
\hline & Mean & S.D. & $\mathrm{AFC}$ & AFC2 & Mean & S.D. & $\mathrm{AFC}$ & AFC2 \\
\hline MS & 29.1 & 6.3 & $* * *$ & $* * *$ & 37 & 8.1 & $* * *$ & $* * *$ \\
\hline GM & 146.0 & 60.3 & $* * *$ & $* * *$ & 230 & 70.1 & $* * *$ & $* * *$ \\
\hline PY & 28.0 & 6.0 & $* * *$ & $* * *$ & 35 & 7.7 & $* * *$ & $* * *$ \\
\hline DP & 34.3 & 7.5 & $* *$ & $*$ & 33.6 & 12.2 & NS & NS \\
\hline DR & 0.001 & 0.0004 & $* * *$ & $* *$ & 0.0014 & 0.0004 & $* * *$ & $* *$ \\
\hline PS & 49.1 & 41.1 & $* * *$ & $* * *$ & 80.7 & 54.7 & $* * *$ & $* * *$ \\
\hline TMY & 7.042 & 1.776 & $* * *$ & $* * *$ & 8.301 .7 & $2,025.8$ & $* *$ & $* *$ \\
\hline CTMY & 7.420 & 2.307 & $* * *$ & $* * *$ & 8.628 .7 & $2,517.0$ & NS & NS \\
\hline
\end{tabular}

Cow, herd year and calving season all significant $(\mathrm{P}<0.001), \mathrm{F} \mathrm{n}=119.580, \mathrm{f} \mathrm{n}=74.986, * \mathrm{P}<0.05, * * \mathrm{P}<0.01, * * * \mathrm{P}<0.001$ and $\mathrm{NS} \mathrm{P}>0.05$, S.D. = Standard deviation

\section{CORRELATION ANALYSIS OF FIRST LACTATION CURVE} PARAMETERS

Correlation analysis among the curve parameters of first lactation was quite similar to the results of the analysis using multiple lactations table 2 , with a few exceptions. The exception in the first place was the higher correlation between GM and DR, which increased from 0.38 in the multiple-lactation analysis to 0.71 in first lactation. This indicated that the level of increase in GM had a bigger and unfavorable impact on DR. This, impacted on the correlation between GM with PS, which went from a favorable (for persistency) negative correlation of -0.31 in the multiple-lactations analysis to an unfavorable correlation of 0.50 in first lactation, decreasing persistency as GM increased.

On the other hand, the positive but low correlations of PS with TMY and CTMY from multiple-lactations 0.09 and 0.04 , respectively, became -0.01 and -0.09 for PS with TMY and GM with CTMY, respectively, which meant favorable persistency as the level of TMY and CTMY increased.

\section{DISCUSION}

The biological model of lactation provides an alternative to lactation curve models based on the fact that estimates two biological parameters MS and DR. The first, accounts for cell's maximum milk secretion rate, as well as the total number of parenchyma cells active during lactation. The second, accounts for the relative decline in cell numbers as lactation progress.

\section{PHENOTYPIC CORRELATIONS}

MS represents the upper limit to the amount of milk the animal is able to produce per day if there was no apoptosis during lactation (Pollott 2000). It had a high phenotypic correlation with PY (0.99), indicating that these two traits are virtually the same, implying that both traits are either the same trait or influenced by the same genes (genetic correlation of 0.99) (Albarran-Portillo and Pollott 2008).

Growing midpoint from the start of lactation to PY (GM) was fairly well correlated with PY, TMY, and CTMY, similar to findings by Horant et al (2005), who reported that a trait similar to GM in this study, was highly correlated with PY and, these two parameters were linked to high total milk yields in first, second and third lactations.

The modest correlation between DR and PS (0.39), and the negatively correlation with TMY and CTMY $(-0.31$ and -0.39 , respectively), were similar to those reported by Pollott and Gootwine (2001) using the biological model to study the lactation curve of the Awassi dairy sheep. For instance, they reported negative correlations between DR and TMY $(-0.23)$, DR and lactation length $(-0.29)$ and DR with DP (-0.15).

\section{ENVIRONMENTAL FACTORS}

The significant differences of cow and herd factors in this study seem to be caused by different genetic potential among cows and different management conditions between herds. This indicated a wide range of variation in terms of herd size and management conditions, influencing individual performance of cows. Similar results but from different species were reported by Pollott and Gootwine (2000), who indicated that factors such as flock (herd in this study), animal, year of calving, season of calving and lactation number were the most important factors that accounted for the large amount of the variation in their study.

Calving year. According to table 3, traits such as PY and TMY showed a sustained year increment. On the contrary persistency worsens as milk yields increased. Similar findings were reported by Horan et al (2005). 
Calving season. Results in this study agree to some extent with the results by Tekerly et al (2000) and Barash et al (2001), who reported higher total milk yields in autumn and winter rather than in winter and spring as the results shown in this study.

A photoperiodic effect may possibly explain the higher milk yields recorded in winter and spring. Cows exposed to short day light through the dry period produce more milk in the following lactation than cows exposed to long days during dry period, as reported by Miller et al (2000).

Similar results but from a different species was reported by Pollott and Goodwine (2004). They found that ewes lambing in January (winter) produced more milk throughout lactation than ewes lambing in other seasons. They identified that short days before lambing had a positive effect on ewe's milk production.

Lactation number. A better persistency in first lactation compared with subsequent lactations has been extensively reported in the literature (Stanton et al 1992, Tekerli et al 2000, Barash et al 2001, Brotherstone et al 2004, Horan et al 2005).

It has been reported that total milk yield reaches its maximum at third lactation (Ben Gara et al 2006), or between lactations 3 to 5 (Rekik et al 2003), which agrees with findings in this study. Interestingly, statistically the highest values of MS, and PY, did not corresponded to the highest TMY or CTMY yields.

\section{AGE AT FIRST CALVING}

The average age at first calving was $28 \mathrm{mo}$, and was slightly lower than 28.9 mo reported by Wall et al (2005).

As expected cow, herd, year and season were significant for all curve parameters $(\mathrm{P}<0.001)$. $\mathrm{AFC}$ and $\mathrm{AFC}^{2}$ had a significant effect on all parameters. In second lactation, $\mathrm{AFC}$ and $\mathrm{AFC}^{2}$ were significant for most of the parameters with exception of DP and CTMY. Curve parameters from third lactation were affected neither by $\mathrm{AFC}$ nor by $\mathrm{AFC}^{2}$ ( $\mathrm{P}>0.05$, not shown).

These increments were lower than the $50 \mathrm{~kg}$ of increase in total milk yield with the increase of 1 mo in AFC reported by Silvestre et al (2005).

Finally, the average age at first calving in this study (28 mo), was farm from ideal according to Ettema and Santos (2004). They pointed out that first cows calving between 23 and 25 mo have better productive performance and better conception rates, than younger or older cows throughout first lactation.

However, it has been reported by Muir et al (2004) that heifers first inseminated at younger age than average, had better persistency of lactation compared with heifers first inseminated at average age (i.e. $16.8 \mathrm{mo}$ ).

A similar trend in milk yields from first calving cows was observed by Khan and Shook (1996). They concluded that increments in milk yields were greater for heifers calving later than cows calving in the earlier years in the period studied by them. They attributed the increments to a genetic and environmental improvement.

It can be concluded that cow, herd, lactation number and age at first calving were the most important factors that determined key features of lactation curve of first calving and multiparous dairy cows; whereas year and season of calving although significant were less determinant to curve parameters. The two-parameter biological model produced parameters (MS and DR) highly correlated with the main curve parameters, providing a biological explanation of the lactation curve.

\section{SUMMARY}

The purpose of this study was to investigate the environmental factors affecting lactation curve parameters derived from a biological model. The biological approach to lactation curve fitted 2 logistic curves to mimic the initial increase in milk secretory cell numbers in early lactation, and the progression of apoptosis in late lactation. Records from 182,987 Holstein-Friesian cows were analysed. Main factors such as cow, herd and lactation number accounted for $74 \%$ of the total sum of squares $(\mathrm{P}<0.001)$. The average age at first calving was 28 months; which had a significant effect on all curve parameters. Increments of age at first calving from 20 to 40 months, were associated with linear increments in total milk yield, and calculated total milk yield. Parameters from the increasing phase of lactation such as maximum secretion potential, growing midpoint from start of lactation to peak yield, and peak yield, were highly correlated amongst themselves $(>0.60)$. Curve parameters, maximum secretion potential and peak yield were highly correlated indicating that these two parameters are practically the same. Additionally, high estimates of maximum secretion potential and peak yield resulted in high total milk yield. The early day of peak had an adverse effect over persistency of lactation given by the high correlation between day of peak and persistency (0.64). Cow, herd, lactation number and age at first calving were the most determining factors on the lactation curve of first calving and multiparous dairy cows.

\section{ACKNOWLEDGMENTS}

The first author acknowledges the financial support of the National Council of Science and Technology (CONACyT) and the Autonomous University of Mexico State (UAEMEX) towards his PhD program. We would also like to acknowledge National Milk Records Ltd. UK for providing the data for this study.

\section{REFERENCES}

Albarran-Portillo B, GE Pollott. 2008. Genetic parameters derived from using a biological model of lactation on records of commercial dairy cows. J Dairy Sci 91, 3639-3648.

Barash H, N Silanikove, A Shamay, E Ezra. 2001. Interrelationships among ambient temperature, day length, and milk yield in dairy cows under a Mediterranean climate. J Dairy Sci 84, 2314-2320.

Ben Gara A, B Rekik, M Bouallegue. 2006. Genetic parameters and evaluation of the Tunisian dairy cattle population for milk yield by Bayesian and BLUP analyses. Livest Sci 100, 142-149.

Brotherstone S, R Thompson, IMS White. 2004. Effects of pregnancy on daily milk yield of Holstein-Friesian dairy cattle. Livest Prod Sci 87, 265-269.

Grossman M, WJ Koops. 1988. Multiphasic analysis of lactation curves in dairy-cattle. J Dairy Sci 71, 1598-1608.

Horan B, P Dillon, DP Berry, P O'Connor, M Rath. 2005. The effect of strain of Holstein-Friesian, feeding system and parity on lactation 
curves characteristics of spring-calving dairy cows. Livest Prod Sci 95, 231-241.

Khan MS, GE Shook. 1996. Effects of age on milk yield: time trends and method of adjustment. J Dairy Sci 79, 1057-1064.

Knight CH, CJ Wilde. 1987. Mammary growth during lactation: implications for increasing milk yield. J Dairy Sci 70, 1991-2000.

Knight CH, CJ Wilde. 1993. Mammary cell changes during pregnancy and lactation. Livest Prod Sci 35, 3-19.

Lee C, EJ Pollak, RW Everett, CE McCulloch. 1995. Multiplicative factors for estimation of daily milk and component yields from single morning or afternoon tests. J Dairy Sci 78, 221-235.

Masselin S, D Sauvant, P Chapoutot, D Milan. 1987. Adjustment Models for the Lactation Curves. Ann Zootech 36, 171-206.

Miller ARE, RA Erdman, LW Douglass, GE Dahl. 2000. Effects of Photoperiodic Manipulation During the Dry Period of Dairy Cows. J Dairy Sci 83, 962-967.

Misztal I. 2006. Properties of random regression models using linear splines. J Anim Breed Genet 123, 74-80.

Morant SV, A Gnanasakthy. 1989. A new approach to the mathematical formulation of lactation curves. Anim Prod 49, 151-162.

Muir BL, J Fatehi, LR Schaeffer. 2004. Genetic relationships between persistency and reproductive performance in first-lactation Canadian Holsteins. J Dairy Sci 87, 3029-3037.

Pollott GE. 2000. A biological approach to lactation curve analysis for milk yield. J Dairy Sci 83, 2448-2458.

Pollott GE, E Gootwine. 2000. Appropriate mathematical models for describing the complete lactation of dairy sheep. Anim Sci 71, 197-207.

Pollott GE, E Gootwine. 2001. A genetic analysis of complete lactation milk production in Improved Awassi sheep. Livest Prod Sci 71, 37-47.

Pollott GE. 2004. Deconstructing milk yield and composition during lactation using biologically based lactation models. J Dairy Sci $87,2375-2387$.
Rekik B, A Ben Gara, M Ben Hamouda, H Hammami. 2003. Fitting lactation curves of dairy cattle in different types of herds in Tunisia. Livest Prod Sci 83, 309-315.

Sargent FD, VH Lytton, OG Wall, Jr. 1968. Test interval method of calculating dairy herd improvement association records. J Dairy Sci 51, 170-179.

Schaeffer LR, JCM Dekkers. 1994. Random regressions in animal models for test-day production in dairy cattle. Proccedings of the fifth world congress on genetics applied to livestock production $18,443-446$.

Silvestre AM, F Petim-Batista, J Colaco. 2005. Genetic parameter estimates of portuguese dairy cows for milk, fat, and protein using a spline test-day model. J Dairy Sci 88, 1225-1230.

Stanton TL, LR Jones, RW Everett, SD Kachman. 1992. Estimating milk, fat, and protein lactation curves with a test day model. J Dairy Sci 75, 1691-1700.

Tekerli M, Z Akinci, I Dogan, A Akcan. 2000. Factors affecting the shape of lactation curves of Holstein Cows from the Balikesir Province of Turkey. J Dairy Sci 83, 1381-1386.

Wall E, S Brotherstone, JF Kearney, JA Woolliams, MP Coffey. 2005. Impact of nonadditive genetic effects in the estimation of breeding values for fertility and correlated traits. J Dairy Sci 88, 376-385.

White IM, R Thompson, S Brotherstone. 1999. Genetic and environmental smoothing of lactation curves with cubic splines. J Dairy Sci 82, 632-638.

Wilde CJ, CH Knight. 1989. Metabolic adaptations in mammary gland during the declining phase of lactation. J Dairy Sci 72, 16791692.

Wilde CJ, LH Quarrie, E Tonner, DJ Flint, M Peaker. 1997. Mammary apoptosis. Livest Prod Sci 50, 29-37.

Wood PDP. 1967. Algebraic model of lactation curve in cattle. Nature (Lond.) 216, 164-165. 